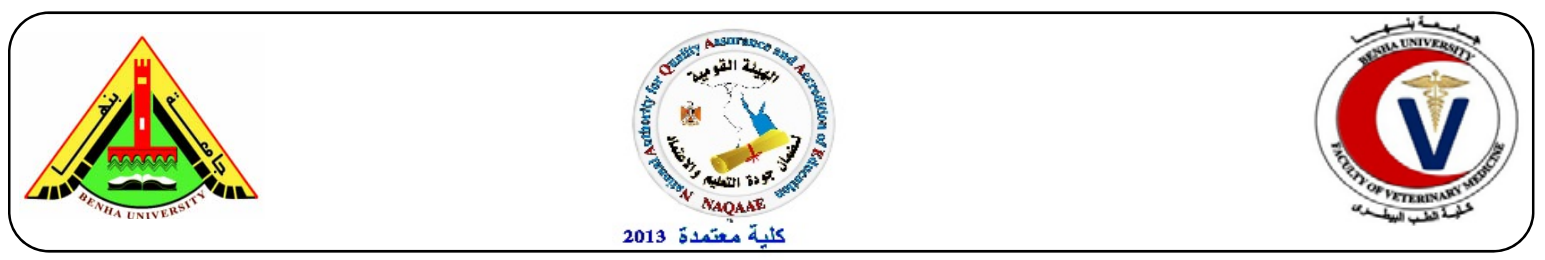

\title{
Preparation of rabies antiserum in tetanus immunized horses
}

\author{
Attyat, M. Kotb and Wafaa, R. Abdel Aziz
}

Veterinary Serum and Vaccine Research Institute; Abassia, Cairo, P.O. Box:131- Fax: (202)

23428321-E.mail:svri@idsc.gov.eg

\section{A B S T R A C T}

The present work deals with the use of previously tetanus immunized horses for preparation of rabies antiserum in addition to investigate the effect of simultaneous immunization of horses against rabies and tetanus in order to prepare a bivalent anti-rabies and tetanus serum. The obtained results of applied serological tests revealed that the presence of tetanus antibodies in previously immunized horses did not affect the levels of induced rabies antibodies while simultaneous immunization resulted in high titers of rabies antibodies $(256 \mathrm{IU} / \mathrm{ml})$ as compared to such titers resulted in horses immunized with rabies vaccine alone $(128 \mathrm{IU} / \mathrm{ml})$. These findings suggest an enhancing action of tetanus antigen on antibody response against rabies and the prepared anti-serum can be used in emergency bite injuries in animals protecting them against both of rabies and tetanus infections as noticed in experimentally rabies infected mice.

Keywords: Rabies, Tetanus, Antiserum, Anti- rabies, Horses

\section{INTRODUCTION}

$\mathrm{R}$ abies is one of the most serious zoonotic diseases representing almost $100 \%$ fatality once the clinical signs developed. The causative agent belongs to the genus Lyssaviruses of the family Rhabdoviridae (WHO, 2013). All mammals are susceptible and can transmit rabies virus, but true reservoirs, which are responsible for ultimate longterm disease maintenance, persist only among Carnivora (mainly carnivorous mammals) and Chiroptera (bats). Specific viruses are adapted to these hosts and typically perpetuate infection within a species before the hosts die. Unvaccinated domestic animals and human become rabid after exposure to such reservoirs (Krebs et al., 2003). The virus is present in the saliva of rabid dogs which inoculate it into the wound thus initiating an exposure. Passive immunization is a very important parameter in post exposure prophylaxis for two reasons: (1) the virus is present at the site of bite for varying periods of time thus amenable to neutralization by passively administered antibodies, and (2) active immunization with vaccines requires a minimum of 10-14 days for producing adequate levels of virus neutralizing antibodies (Madhusudana et al., 2013). Tetanus toxoid (TT) could stimulate different cellular components, and can therefore be used to assess different compartments of the immune mechanism. (Spiers et al. 1978). Dog bite could lead to local wound infection, tetanus, or rabies that could come from either the saliva of biter, skin flora of victim, or the environment. So passive immunization in case of high risk wound is needed for protection against tetanus and rabies. The present study was conducted in a trial to increase the titer of the prepared anti-rabies serum, and to investigate the effect of tetanus inoculation on horses used for preparation of anti-rabies serum 


\section{MATERIAL AND METHODS}

\subsection{Animals:}

2.1.1. Horses: Nine local breed healthy horses of about 1.5- 2 years old; free from external and internal parasites and had no history of rabies vaccination; were used for preparation of anti-rabies hyper-immune serum divided into 5 groups as follow: Group-1 of two horses immunized against tetanus. *Group- 2 of two horses immunized with rabies inactivated cell culture vaccine alone, not previously immunized with tetanus. Group-3 of two horses previously immunized against tetanus from one month and immunized with rabies inactivated cell culture vaccine. Group-4 of two horses immunized simultaneously with tetanus antigen and rabies vaccine. Group-5 of one horse kept as non-immunized control, not previously immunized against rabies or tetanus.

2.1.2. Mice: Eighty weaned Albino Swiss mice were used to test the safety and potency of the prepared anti-sera. In safety, 20 mice were used through inoculation of $0.5 \mathrm{ml} /$ mouse intraperitoneally (IP). In potency test, 60 mice were experimentally infected with CVS virus at a dose of $0.03 \mathrm{ml}$ containing $10^{3} \mathrm{MLD} 50 / \mathrm{ml}$ inoculated intracerebrally $(\mathrm{I} / \mathrm{C})$ They were divided into 10 groups ( 5 mice / group) where one group of them was inoculated (IP) with $0.5 \mathrm{ml}$ of rabies antisera from day of infection up to 10 days later. Other 10 mice were infected and kept without treatment as control.

\subsection{Rabies vaccine:}

A locally prepared inactivated cell culture rabies vaccine, prepared according to Edries (1994) was supplied by the Department of Pet Animal Vaccine Research (DPAVR), Veterinary Serum and Vaccine Research Institute, Abbasia, Cairo was used for preparation of antiserum in horses.

\subsection{Viruses:}

\subsubsection{Live attenuated rabies virus; ERA (Evelyn Rokitincki Abelesth):}

BHK-21 cell culture adapted strain of rabies virus (ERA) of a titer $10^{7}$ TCID $50 / \mathrm{ml}$ (Edries, 1994) was supplied by the same department and used in serological tests for titration of rabies antibodies in the prepared anti-sera.

\subsubsection{Challenge virus strain (CVS):}

Mice brain adapted rabies virus with a titer of $10^{5} \mathrm{MID} 50 / \mathrm{ml}$ was supplied by DPAVR and used for experimentally infection of mice using a dose of $0.03 \mathrm{ml} /$ mouse through the intracerebral route.

\subsection{Tetanus toxin:}

The toxin was prepared according to Anon (1980) from the toxigenic Harvard strain of Clostridium tetani which was grown on Mueller and Miller medium (1954) for 8-10 days at $35^{\circ} \mathrm{c}$ aerobically. The prepared toxin had $80 \mathrm{Lf} / \mathrm{ml}$ as measured by flocculation test and adjuvanted with alum $(0.5 \%)$ where it was inoculated weekly in increasing doses I/M (10;20; 30 and $40 \mathrm{ml} /$ horse) for production of anti-tetanic serum.

\subsection{Tetanus toxoid:}

Reference tetanus toxoid measuring 2450 $\mathrm{Lf} / \mathrm{ml}$ was purchased from the Holding Company for Biological Products and Vaccines; VACSERA, Agouza and used for evaluation of the produced anti-tetanic serum.

\subsection{Preparation of anti-rabies hyper immune serum:}

It was prepared in horses by subcutaneous $\mathrm{S} / \mathrm{C}$ injection of multiplied doses of rabies vaccine $(4 ; 8 ; 16$ and $32 \mathrm{ml} /$ horse) on week intervals up to 4 weeks.

Serum samples were obtained from all horses on week intervals post inoculation and 14 days after the last injection.

\subsection{Evaluation of the prepared antisera:}

The prepared antisera were subjected to the quality control tests (freedom of foreign contaminants; safety and potency) following the directions of WHO (1992).

\subsection{Ramon Flocculation test:}


This test was carried out according to (WHO, 1997) to estimate tetanus antibodies using increasing volumes of the reference toxoid $(100 \mathrm{Lf} / \mathrm{ml})$ and fixed serum volume ( $1 \mathrm{ml})$ of the serum under test and the Lf value of the serum was calculated from the concentration of toxin content in flocculation tubes.

\subsection{Serum neutralization test (SNT):}

SNT was carried out using the microtiter technique according to Rossiter et al. (1985) and the titer of rabies serum neutralizing antibody titer was calculated according to Reed and meunch (1938).

\subsection{Indirect Enzyme linked immune sorbent Assay (ELISA)}

SERELISA rabies antibody Mono kit was supplied by Symbiotic Europe SAS 2 Lyon Cedex 07 allow quantitative detection of rabies prepared antisera and a minimum of $0.5 \mathrm{IU} / \mathrm{ml}$ rabies antibodies is required to protect against rabies infection according to WHO (1992).

\section{RESULTS}

\subsection{Results of quality control on the prepared anti-sera:}

As shown in (table-1) the obtained results revealed that the prepared horse anti-rabies and anti-tetanus hyper immune sera were free from foreign contaminants (aerobic and anaerobic bacteria; fungi and mycoplasma) and safe when inoculated in mice showing no significant local or systemic reactions or deaths.

\subsection{Mean rabies serum neutralizing antibody titers in immunized horses:}

Serum neutralization test indicated that the prepared antiserum in horses used routinely for tetanus antibody production, and those which are simultaneously inoculated by rabies and tetanus (group $3 \& 4$ ) had a titer of $256 \mathrm{IU} / \mathrm{ml}$ compared to group 2 with a titer of $128 \mathrm{IU} / \mathrm{ml}$ prepared in horses without tetanus inoculation (table 2).

\subsection{Anti-tetanic serum titer in immunized horses as measured by flocculation test:}

Tetanus antibody titer increased gradually from $200 \mathrm{Lf} / \mathrm{ml}$ at the beginning of the experiment to $500 \mathrm{Lf} / \mathrm{ml} 2$ weeks after the last injection, in group 1 and 4 . While in group3 which did not receive tetanus toxin, the antibody titer declined from $470 \mathrm{Lf} / \mathrm{ml}$ to $250 \mathrm{Lf} / \mathrm{ml}$ by the end of the experiment as shown in (Table 3 )

\subsection{Potency of the prepared rabies antisera in mice:}

Table 4 showed that the experimental infection of mice with CVS could be stopped by treating them with the prepared rabies anti-serum on the day $0,1,2$ and 3 but treatment after the third day lead to decreased mice protection.

Table (1): Quality control parameters of the prepared anti-sera

\begin{tabular}{|c|c|c|c|}
\hline Tested antiserum & Sterility & Antibody titer & Safety in mice \\
\hline Tetanus alone & & $500 \mathrm{Lf} / \mathrm{ml}$ & \\
\hline Rabies alone & $\uparrow$ & $128 \mathrm{Lf} / \mathrm{ml}$ & $\uparrow$ \\
\hline $\begin{array}{l}\text { Rabies in previously tetanus immunized } \\
\text { horses }\end{array}$ & Free from & $128 \mathrm{Lf} / \mathrm{ml}$ & $\begin{array}{l}\text { No significant } \\
\text { local or systemic }\end{array}$ \\
\hline $\begin{array}{l}\text { Simultaneous rabies and tetanus } \\
\text { Negative control }\end{array}$ & - & $\begin{array}{c}256 \mathrm{Lf} / \mathrm{ml} \\
0\end{array}$ & $\begin{array}{c}\text { reactions or } \\
\text { deaths } \downarrow\end{array}$ \\
\hline
\end{tabular}


Table (2): Mean rabies serum neutralizing antibody titers in immunized horses

\begin{tabular}{ccccc}
\hline W PI* & \multicolumn{3}{c}{ Rabies antibody titer in horse groups (IU/ml) } \\
& Group2 & Group3 & Group4 & Group5 \\
\hline Pre-immunization & 0 & 0 & 0 & 0 \\
1 & 32 & 32 & 32 & 0 \\
2 & 64 & 64 & 64 & 0 \\
3 & 64 & 128 & 128 & 0 \\
4 & 128 & 256 & 256 & 0 \\
5 & 128 & 256 & 256 & 0
\end{tabular}

Group-2 of two horses immunized with rabies inactivated cell culture vaccine alone. Group-3 of two horses previously immunized against tetanus and immunized with rabies inactivated cell culture vaccine. Group-4 of two horses immunized simultaneously with tetanus antigen and rabies vaccine. Group 5 control non vaccinated horse. ${ }^{*} \mathrm{~W} \mathrm{PI}=$ Weeks post inoculation.

Table (3): Anti-tetanic serum titer in immunized horses as measured by flocculation test.

\begin{tabular}{ccccc}
\hline \multirow{2}{*}{ W PI $^{*}$} & \multicolumn{3}{c}{ Anti-tetanic serum titer in horse groups(Lf /ml) } \\
Proup1 & Group3 & Group 4 & Group 5 \\
\hline 1 & 200 & 470 & 200 & 0 \\
2 & 250 & 450 & 260 & 0 \\
3 & 320 & 400 & 360 & 0 \\
4 & 360 & 360 & 400 & 0 \\
5 & 400 & 320 & 450 & 0 \\
& 500 & 250 & 500 & 0
\end{tabular}

Group 1 of two horses immunized against tetanus. Group 3 of two horses previously immunized against tetanus and immunized with rabies inactivated cell culture vaccine. Group- 4 of two horses immunized simultaneously with tetanus antigen and rabies vaccine. Group 5 control unvaccinated horse. ${ }^{*} \mathrm{~W}$ PI= Weeks post inoculation.

Table (4): Potency of the prepared rabies antisera in mice

\begin{tabular}{cccccccccc}
\hline Infected mice & \multicolumn{10}{c}{ Days of passive immunization post experimental } & infection \\
\hline 50 & 0 & $1 \mathrm{dpi}^{*}$ & $2 \mathrm{dpi}$ & $3 \mathrm{dpi}$ & $4 \mathrm{dpi}$ & $5 \mathrm{dpi}$ & $6 \mathrm{dpi}$ & $7 \mathrm{dpi}$ \\
$\begin{array}{c}\text { No of pim } \\
\text { No of survived }\end{array}$ & 5 & 5 & 5 & 5 & 5 & 5 & 5 & 5 \\
$\begin{array}{c}\text { mice } \\
\text { Protection \% }\end{array}$ & 5 & 5 & 5 & 5 & 2 & 1 & 0 & 0 \\
*dpi = days post infection & 100 & 100 & 100 & 100 & 40 & 20 & 0 & 0 \\
\hline
\end{tabular}




\section{DISCUSSION}

Several different rabies immunoglobulin products are available but access to them is limited by global shortages and high cost. Rabies immunoglobulin provides passive antibodies at the site of exposure. It is given once, as soon as possible providing sufficient protection till patient develop an active immune response. The recommended total dose is $20 \mathrm{IU} / \mathrm{kg}$ body weight. (Knobel et al., 2005). Also tetanus is an acute toxemic illness caused by Clostridium tetani infection at a laceration or break in the skin. It can also occur as a complication of burns, puerperal infections, umbilical stumps (tetanus neonatorum) and surgicalsite infection. (Brook, 2008). Therefore, bitten animals should be inoculated with tetanus serum and rabies vaccine and antiserum. The obtained results (Table1) revealed that the prepared horse anti-rabies and anti-tetanus hyper immune sera were free from foreign contaminants (aerobic and anaerobic bacteria; fungi and mycoplasma) and safe when inoculated in mice showing no significant local or systemic reactions or deaths. These findings come in agreement with the recommendations of WHO (1996). Antibody titer of rabies was noticed to increase gradually from the $1^{\text {st }}$ to the $4^{\text {th }}$ week of horse immunization as shown in (table 2). Serum neutralization test indicated that the prepared antiserum in horses used routinely for tetanus antibody production, and those which are simultaneously inoculated by rabies and tetanus (group 3\&4) had a titer of $256 \mathrm{IU} / \mathrm{ml}$ compared to group 2 with a titre of 128 $\mathrm{IU} / \mathrm{ml}$ prepared in horses without tetanus inoculation (table 2). These findings were supported by previous studies which showed the enhancing effect of tetanus toxoid (TT) when coupled with different microbial agents. Soliman et al., (1996) used TT combined with African Horse Sickness (AHS) vaccine in order to increase the immunizing ability of AHS vaccine. They found that ELISA antibody titer in sera of horses vaccinated with combined
AHS and TT was 100 IU but horses vaccinated with AHS vaccine alone gave 50 IU. Also, Watson et al., (1992) declared that using TT conjugated with Salmonella typhimurium with an 0 -specific polysaccharide protein conjugate vaccine elicited antibody in outbred mice, while antigen without TT didn't produce antibodies. Elizabeth et al., (1996) concluded that tetanus toxoid have a role on the activation of cell mediated immunity, peripheral mononuclear cells (PBMC) which have the ability to produce cytokines characteristic of Th1 or Th2 cells (interferon $\{$ IFN $\}-\gamma$ or interleukin $\{I L\}-4$, respectively). Estimation of rabies antibodies in immunized horses using serum neutralization test showed high titer $(256 \mathrm{IU} / \mathrm{ml})$. This appears to be supported by those of WHO (1992), Edries et al. (1999) and Khodier and Daoud (2008) suggesting that this serum is hyper-immune where the protective rabies antibody titer shouldn't be less than $0.5 \mathrm{IU} / \mathrm{ml}$. Tetanus antibody titer increased gradually from 200 $\mathrm{Lf} / \mathrm{ml}$ at the beginning of the experiment to $500 \mathrm{Lf} / \mathrm{ml} 2$ weeks after the last injection, in group 1 and 4 . While in group3 which did not receive tetanus toxin, the antibody titer declined from $470 \mathrm{Lf} / \mathrm{ml}$ to $250 \mathrm{Lf} / \mathrm{ml}$ by the end of the experiment. Rabies vaccine did not affect tetanus antibody titer. (Table 3 ). Table 4 showed that the experimental infection of mice with CVS could be stopped by treating them with the prepared rabies anti-serum on the day $0,1,2$ and 3 but treatment after the third day lead to decreased mice protection. This comes in agreement with Khodier and Daoud (2008) and Albehwar (2011) who concluded that the best administration of rabies immunoglobulin is from the first to third day post exposure.

Therefore, the present study shows the possibility of simultaneous production of poly specific serum of both rabies and tetanus in the same horse reducing the antigen load, animal handling and cost. In the same time, it has a beneficial effect to bitten animals which needs both rabies and 
tetanus immunoglobulins so reducing shots and handling of infected animals.

\section{REFERENCES}

Albehwar, A.M. 2011. The use of rabies immunoglobulin in rabies infection simulated in mice. $29^{\text {th }}$ Arab Vet. Medical Congress, pp. 28-30.

Anon 1980. Instructions for the preparation of vaccines. Rijks institute voor volksgezondheid Bilthoven, the Netherlands.

Brook, I. 2008. Current concepts in the management of Clostridium tetani infection. Expert Rev Anti Infect Ther. 6(3):327-36.

Edries, S.M. 1994. Production of inactivated tissue culture rabies vaccine. Ph.D. Thesis, Fac. Vet. Med. Cairo Univ.

Edries, S.M., Khodier, M.H., Habasi, Y.Z. 1999. Production and evaluation of rabies hyper immune-serum for serological tests. $5^{\text {th }}$ Sci Cong. Soc. Cattle Dis., Assiut, Egypt. pp. 176-179.

Elizabeth, A. Sabin, Maria, I. Araujo Edgar, Carvalho, M., Edward, J. 1996. Pearce impairment of tetanus toxoid-specific Th1-like immune response in humans infected with schistosoma mansoni. The journal of infectious diseases, 173(1):269-272.

Khodier, M.H., Daoud, A.M. 2008. Preparation of Anti-Rabies Hyper-immune serum for emergency immunization of farm animals Proc $4^{\text {th }}$ Inter Conf. Vet. Res. Div. NRC Cairo, EGYPT, pp.1-9.

Knobel, D.L., Cleveland, S., Coleman, P.G., Fèvre, E.M., Meltzer, M.I., Miranda, M.E. 2005. Re-evaluating the burden of rabies in Africa and Asia. Bull World Health Organ. 83:360-8.

Krebs, J.W., Wheeling, J.T., Childs, J.E. 2003. Rabies surveillance in the United States during 2002. J Am Vet Med Assoc. 223: 1736- 48.

Madhusudana, S.N., Ashwin, B.Y., Sudarshan, S. 2013. Feasibility of reducing rabies immunoglobulin dosage for passive immunization against rabies. Results of in vitro and in vivo studies. Human Vaccines \& Immuno-therapeutics, 9(9): 1914-1917.

Mueller, J.H., Miller, P.A. 1954. Variable factors influencing the production of tetanus toxin. J. Bact., 67: 271-277.

Reed, L.J., meunch, H. 1938. A simple method of estimating fifty per cent endpoints. Am. J. Epidemiol. 27(3):493-497.

Rossiter, P.B., Jessett, D.M., Taylor, W.P. 1985. Micro-neutralization system for use with different strains of peste des petits ruminants and rinderpest virus. Tropical Animal Health and Production 17:75-81.

Soliman, I.M., El-Kabbany, M., Magda, A. Kaldas, Abd-ElBakey, A.H. 1996. Immune response in horses vaccinated with combined African horse sickness freeze-dried vaccine and TT. Asuit. Vet. Med. J., 35(70):45-48.

Speirs, R.S., Benson, R.W., Knowles, B.J. 1978. Models for assessing the effect of toxicants on immunocompetence in mice. II. Effect of cyclophosphamide on the antibody responses to type III pneumococcal polysaccharide and tetanus toxoid in BALB/c female mice. $\mathrm{J}$ Environ Pathol Toxico. 1(6):791-812.

Watson, D.C., Robbin, I.B., Szu, S.C. 1992. Protection of mice against Salmonella typhimurium with an O-specific polysaccharide protein conjugate vaccine. J. Infection-Immunity, 60(11): 4679-4686.

WHO (World Health Organization) 1992. Expert Committee on Rabies. WHO Tech. Report Series 824, pp. 84

WHO 1996. WHO monograph (Laboratory techniques in rabies $3^{\text {rd }}$ Ed Geneva, world health organization series, 23:101- 123.

WHO 1997. A WHO guide to good manufacturing practice (GMP) requirements.

WHO (World Health Organization) 2013. Expert consultation on rabies, second report: WHO Technical Report Series 982. Geneva. 